\title{
PENINGKATAN HASIL BELAJAR PESERTA DIDIK MELALUI PENERAPAN MODEL DISCOVERY LEARNING PADA MATERI EKOSISTEM
}

\author{
Aulia Agrindha Ulfah ${ }^{1 *}$, Dewi Jumiarni ${ }^{1}$, Yennita $^{1}$ \\ ${ }^{1}$ Program Studi Pendidikan Biologi, Fakultas Keguruan Dan Ilmu Pedidikan, Universitas Bengkulu \\ Email: aulia.agrindha@gmail.com
}

\begin{abstract}
Abstrak
Penelitian ini bertujuan untuk mendeskripsikan peningkatan hasil belajar peserta didik dengan menggunakan model Discovery Learning di kelas VII B SMPN 22 Kota Bengkulu. Jenis penelitian ini adalah Penelitian Tindakan Kelas dengan metode deskriptif. Penelitian ini terdiri dari dua siklus, masing-masing siklus terdiri dari 4 tahap yaitu: tahap perencanaan, pelaksanaan, pengamatan dan refleksi. Subjek penelitian ini adalah guru dan seluruh peserta didik kelas VII B SMPN 22 Kota Bengkulu. Instrumen penelitian yang digunakan adalah lembar tes. Hasil analisis persentase ketuntasan belajar peserta didik ranah kognitif yaitu 53,12\% di siklus I menjadi $75 \%$ di siklus II. Sedangkan ranah psikomotor rerata skor pada siklus I adalah 9,28 dengan kategori cukup dan meningkat pada siklus II menjadi 10,63 dengan kategori baik. Berdasarkan Penelitian Tindakan Kelas (PTK) yang telah dilaksanakan pada Kelas VIIB SMPN 22 Kota Bengkulu dengan menerapkan model Discovery Learning pada materi Sistem Koordinasi dapat meningkatkan hasil belajar peserta didik.
\end{abstract}

Kata Kunci : Discovery Learning dan Hasil Belajar Peserta Didik

\begin{abstract}
This research aims to describe the improvement in student learning outcomes by using the Discovery Learning model in class of VII B of junior high school 22 Bengkulu City. This type of research is Classroom Action Research with descriptive methods. This study consists of two cycles, each cycle consisting of four stages, namely: the stages of planning, implementation, observation and reflection. The subjects of this research were teachers and all students of class VII B of junior high school 22 Bengkulu City. The research instrument used was a test sheet. The results of the analysis of the percentage of learning mastery of cognitive students were $53.12 \%$ in the first cycle to $75 \%$ in the second cycle. While the mean psychomotor domain score in the first cycle was 9.28 with sufficient categories and increased in the second cycle to 10.63 in the good category. Based on Classroom Action Research (CAR) which has been carried out in Class of VIIB of junior high school 22 Bengkulu City by applying the Discovery Learning model in the material the Coordination System can improve student learning outcomes.
\end{abstract}

Keywords : Discovery Learning and Learning Outcomes of Students

\section{PENDAHULUAN}

Menurut Suwarno (2014)

Pendidikan merupakan usaha manusia untuk membina kepribadiannya sesuai dengan nilai-nilai didalam masyarakat dan kebudayaan. pendidikan terdapat hubungan antara pendidik dan peserta didik. Dalam hubungan itu, mereka memiliki kedudukan dan perasaan yang berbeda. Tetapi keduanya memiliki daya yang sama, yaitu saling mempengaruhi guna terlaksananya proses pendidikan (transformasi pengetahuan dan keterampilan-keterampilan yang tertuju kepada tujuan yang diinginkan).

Menurut Suprijono (2012) hasil belajar adalah pola-pola perbuatan, nilainilai, pengertian-pengertian, sikap-sikap, apresiasi dan ketrampilan. Dimyati dan Mudjiono (2009) juga mengatakan bahwa hasil belajar merupakan hasil dari suatu interaksi tindak belajar dan tindak mengajar. Dari sisi guru, tindak mengajar diakhiri dengan proses evaluasi hasil belajar. Dari sisi siswa, hasil belajar 
merupakan berakhirnya pengajaran dari puncak proses belajar.

Berdasarkan hasil wawancara yang dilakukan peneliti terhadap guru IPA SMPN 22 Kota Bengkulu, diperoleh informasi seperti: (a) proses pembelajaran IPA pada kelas VIIB SMPN 22 Kota bengkulu hanya berpusat dengan guru sehingga minat belajar siswa pada pelajaran IPA berkurang; (b) Model pembelajaran yang digunakan yaitu model DI (direct instruction) atau pengajaran langsung. Kemudian informasi kendala belajar yang dialami siswa, yaitu: (a) siswa kurang mampu membangun pengetahuan sendiri dan lebih suka mendengar ceramah dari guru, (b) hanya beberapa siswa saja di kelas yang mampu dan berani mengemukan pendapatnya mengenai materi pembelajaran.

Permasalahan

tersebut

berpengaruh terhadap hasil belajar siswa, karena saat belajar siswa lebih suka mengandalkan penjelasan dari guru saja tanpa mencari informasi untuk membangun pengetahuan sendiri. Pembelajaran akan lebih efektif apabila siswa lebih aktif berpartisipasi dalam proses pembelajaran. Melalui partisipasi yang lebih aktif, siswa akan dapat memahami pelajaran sehingga meningkatkan hasil belajarnya. Berdasarkan hasil informasi dari guru mata pelajaran IPA di sekolah, menyatakan bahwa hasil belajar siswa kelas VIIB SMPN 22 Kota Bengkulu dalam aspek pengetahuan atau kognitif masih kurang, hal ini karena masih banyak siswa yang belum mencapai kriteria ketuntasan minimal (KKM) yaitu 73.

Untuk memperbaiki dan mencapai hasil pembelajaran yang optimal, maka dilakukan kolaborasi guru IPA dengan peneliti sebagai salah satu usaha untuk meningkatkan hasil belajar siswa dalam pembelajaran IPA di kelas VIIB SMPN 22
Kota Bengkulu yaitu dengan melakukan Penelitian Tindakan Kelas (PTK).

Penelitian ini bertujuan utuk mendeskripsikan peningkatan hasil belajar peserta didik kogitif dan psikomotor. Pada kognitif nilai siswa masih banyak di bawah KKM. Sedangkan psikomotorik pada siswa dalam proses belajar masih kurang, karena siswa masih terpaku pada penjelasan dari guru. Peneliti dan guru telah sepakat untuk menerapkan model discovery learning untuk melihat aktivitas mengajar guru dan siswa serta hasil belajar peserta didik.

Pemilihan model ini karena melihat kecocokan antara model discovery learning dengan materi Ekosistem. Menurut Sani, Ridwan Abdul, dkk (2014) model discovery learning ini merupakan salah satu model pembelajaran yang dapat diterapkan dan sesuai dengan pendekatan saintifik, seperti kemampuan untuk bertanya, mengobservasi, mengumpulkan informasi, mengolah informasi, dan membuat kesimpulan berdasarkan data atau informasi sehingga dapat menemukan hubungan antar variabel atau menguji hipotesis yang diajukan. Sehingga kegiatan discovery learning melalui kegiatan dapat menambah pengetahuan dan keterampilan peserta didik secara simultan.

Model penemuan (discovery learning) sangat cocok untuk di terapkan dalam meningkatkan hasil belajar terutama siswa ditingkat SMP. Ada beberapa hasil penelitian relevan yang telah menggunakan model penemuan (discovery learning) sebagai model pembelajaran untuk meningkatkan hasil belajar.

Adapun diantaranya penelitian oleh Fitri, Mariza, dkk (2015) menyatakan bahwa dengan menggunakan model Discovery Learning dapat meningkatkan 
hasil belajar peserta didik kelas $\mathrm{X}$ Semester II SMA Cerdas Murni Tembung dengan ketuntasan klasikal 70,3\% menjadi $75,83 \quad \%$ Berdasarkan permasalahan $\mathrm{di}$ atas peneliti akan melaksanakan penelitian untuk melakukan perbaikan pembelajaran dengan judul penelitian "Penerapan Model Pembelajaran Discovery Learning untuk Meningkatkan Hasil Belajar IPA Peserta didik Kelas VIIB SMPN 22 Kota Bengkulu".

\section{METODE}

Jenis penelitian yang digunakan adalah penelitian tindakan kelas (PTK) (Kunandar, 2013). Metode penelitian yang digunakan dalam penelitian ini adalah metode deskriptif (Sugiyono, 2017). Subyek penelitian ini adalah guru dan peserta didik. Guru IPA dan peneliti berkolaborasi untuk mencapai hasil belajar yang optimal. Sedangkan peserta didik dalam penelitian ini adalah seluruh peserta didik kelas VIIB SMPN 22 Kota Bengkulu. Peserta didik berjumlah 32 orang, terdiri dari 19 peserta didik lakilaki dan 13 peserta didik perempuan.

Teknik yang digunakan untuk mengumpulkan data pembelajaran dalam penelitian ini adalah teknik observasi dan tes. Sedangkan instrumen yang digunakan adalah lembar observasi dan lembar tes. Lembar observasi psikomotor peserta didik digunakan untuk mengobservasi penilaian hasil belajar peserta didik ranah psikomotor dalam kegiatan pembelajaran dengan model Discovery Learning.

Bentuk tes yang digunakan dalam penelitian ini adalah tes objektif. Dalam bentuk pilihan ganda. Teknik analisis data yang digunakan pada penelitian ini yaitu secara deskriptif. Menurut Sudijono (2014), untuk menentukan ketuntasan belajar klasikal dari data nilai hasil belajar (kognitif) peserta didik dihitung dengan menggunakan rumus berikut :

$$
\mathrm{P}=\frac{\sum X}{N} \mathrm{X} 100 \%
$$

Sudijono (2014)

Keterangan :

$\Sigma x \quad$ : Jumlah peserta didik yang berada di bawah/di atas KKM

$\mathrm{N} \quad$ : Jumlah seluruh peserta didik

P : Persentase ketuntasan hasil belajar peserta didik

Menurut ketentuan yang ditetapkan SMPN 22 Kota Bengkulu, peserta dikatakan tuntas pada mata pelajaran IPA biologi apabila KKM $\geq 73$. Sedangkan pada ketuntasan belajar kalsikal, peserta didik dikatakan tuntas belajarnya apabila $\geq 70 \%$ dari jumlah peserta didik telah memperoleh nilai $\geq 73$.

Adapun teknik dalam menganalisis data observasi menggunakan rumus berikut ;

Rata-rata skor $=$

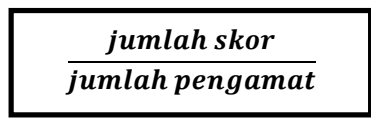

Arikunto (2010)

Skor tertinggi $=$ Jumlah aspek yang diamati X Skor tertinggi tiap aspek

Skor terendah = Jumlah aspek yang diamati X Skor terendah tiap aspek

Selisih skor $=$ Skor Tertinggi-Skor

Terendah

Kisaran nilai tiap kriteria $=$

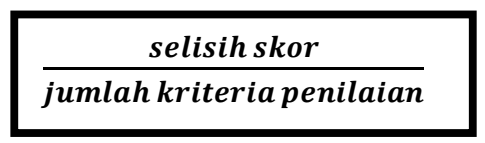

Arikunto (2010)

Lembar observasi psikomotorik, menurut Arikunto (2012) peserta didik 
berjumlah 4 butir pengamatan, skor tertinggi tiap butir 3 dan skor terendah tiap butir 1, maka kategori penilaian untuk lembar observasi psikomotor peserta didik dapat dilihat pada Tabel 1 .

Tabel 1. Interval Kategori Penilaian Lembar Observasi Hasil Belaja (Psikomotor)

\begin{tabular}{cc}
\hline Rentang Skor & Kategori Penilaian \\
\hline $4-6$ & Kurang \\
$7-9$ & Cukup \\
$10-12$ & Baik \\
\hline
\end{tabular}

\section{HASIL DAN PEMBAHASAN}

Adapun hasil dari pelaksanan penilaian hasil belajar ranah kognitif peserta didik pada siklus I dan II dapat dilihat pada Gambar 1 :

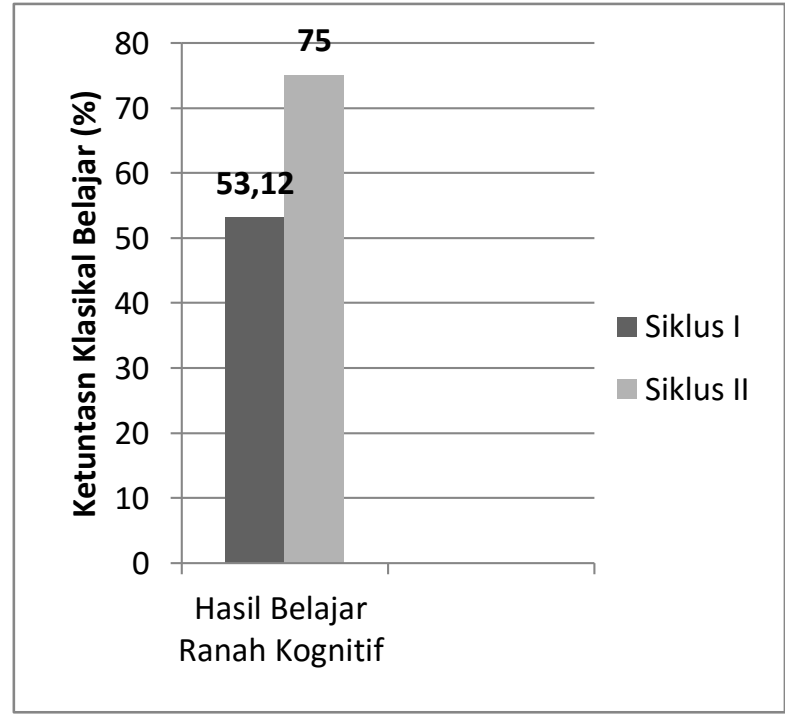

Gambar 1. Diagram Persentase Ketuntasan Klasikal Hasil Belajar Peserta Didik Ranah Kognitif Siklus I dan II

Berdasarkan Gambar 1 tersebut, diketahui bahwa hasil belajar peserta didik ranah kognitif pada siklus I yaitu $53,12 \%$ (belum tuntas), meningkat menjadi $75 \%$ (tuntas) pada siklus II. Kemudian hasil dari pelaksanan observasi hasil belajar ranah psikomotor peserta didik pada siklus I dan II pada Gambar 2.

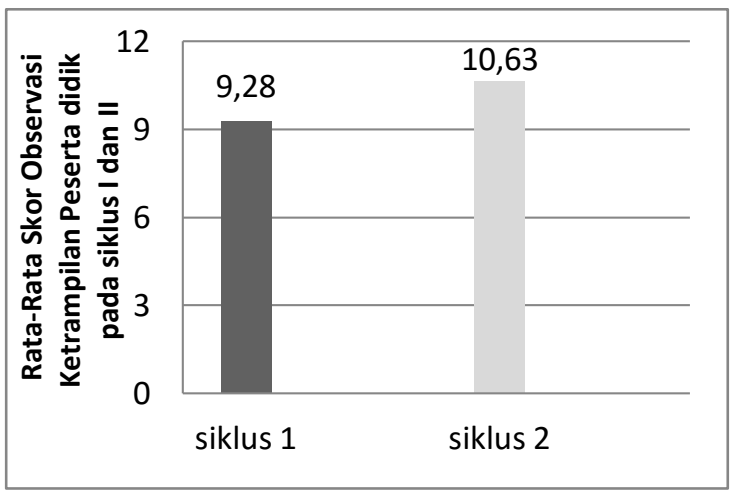

Gambar 2. Diagram Rata-Rata Skor Observasi Psikomotor Peserta Didik pada Siklus I dan II

Dari data observasi hasil belajar ranah psikomotor peserta didik (Gambar 2) pada siklus I diperoleh rerata skor observasi untuk seluruh peserta didik adalah 9,28 termasuk dalam kategori cukup. Jumlah peserta didik yang mendapat nilai baik dapat dilihat berdasarkan lembar deskriptor observasi psikomotor, di siklus I ada 14 orang dari 32 jumlah keseluruhan peserta didik kelas VIIB, dengan persentase 43,75\%. Sedangkan peserta didik yang mendapat nilai cukup sebanyak 18 orang dengan persentase $56,25 \%$.

Pada siklus II terjadi peningkatan dari siklus I, rerata skor observasi seluruh peserta didik adalah 10,63 termasuk kategori baik. Jumlah peserta didik yang yang mendapatkan nilai berkategori baik berdasarkan lembar deskriptor observasi psikomotor ada 28 orang dengan persentase $87,5 \%$ dan jumlah peserta didik yang medapatkan nilai cukup sebanyak 4 orang dengan persentase $12,5 \%$.

Pada tahap kegiatan inti pembelajaran, terdapat beberapa aktivitas guru dan aktivitas peserta didik dalam setiap sintaks pembelajaran dengan model pembelajaran Discovery Learning sebagai berikut :

1. Stimulasi (pemberian rangsangan) 
Pada tahap stimulasi terdapat satu indikator kegiatan mengajar yang dilakukan oleh guru yakni guru memberikan pertanyaan penyelidikan kepada peserta didik. Aktivitas guru pada tahap stimulasi di siklus I ini belum berjalan dengan baik. Hal ini dikarenakan salah satu dari pengamat memberikan skor dengan kategori cukup yang berarti bahwa guru memberikan pertanyaan penyelidikan tidak berasal dari fenomena yang terjadi namun sesuai dengan topik pembelajaran.

Pertanyaan yang diberikan pada tahap stimulasi bertujuan untuk menimbulkan rasa ingin tahu peserta didik terhadap materi yang akan dipelajari. Sesuai dengan pernyataan Widiadnyana, dkk (2014), tahapan pertama yaitu stimulation, dengan memberikan pertanyaan-pertanyaan yang relevan dengan kehidupan sehari-hari, yang merangsang siswa untuk berpikir serta dapat mendorong eksplorasi. Timbulnya sikap keingintahuan untuk menyelidiki sendiri dan tuntutan eksplorasi, maka akan mengarahkan pemikiran siswa untuk memahami terutama tentang permasalahan yang menjadi topik pembelajaran.

2. Identifikasi Masalah

Pada tahap identifikasi masalah ini terdapat satu indikator kegiatan mengajar guru yakni, guru mengarahkan peserta didik untuk mengemukakan pendapatnya tentang pertanyaan yang telah diberikan dan mengarahkan peserta didik menyampaikan pendapat lain berupa masalah yang sesuai dengan pertanyaan guru. Sedangkan aktivitas peserta didik mengemukakan pendapat mengenai pertanyaan yang telah diberikan oleh guru.Kegiatan guru baik di siklus I maupun di siklus II telah berjalan dengan baik. Guru meminta seluruh kelompok peserta didik untuk mengemukakan pendapatnya terkait dengan pertanyaan yang telah disampaikannya.

Kegiatan tersebut sesuai dengan pernyataan Nurgazali (2019) yang menyatakan bahwa pada tahap identifikasi masalah guru memberikan kesempatan kepada siswa untuk mencari dan mengumpulkan sebanyak mungkin masalah yang berhubungan dengan tema yang akan dipelajari.

3. Pengumpulan data

Pada tahap pengumpulan data terdapat dua indikator kegiatan diantaranya yaitu pertama, guru menjelaskan prosedur kegiatan pada LKPD dan kedua, membimbing kelompok peserta didik dalam mengumpulkan data diskusi materi menganai komponen biotik dan abiotik pada ekosistem. Aspek guru menjelaskan prosedur kegiatan pengerjaan LKPD, di siklus I maupun siklus II mendapatkan skor baik. Guru menjelaskan prosedur pengerjaan LKPD dengan sistematis. Dari siklus I hingga siklus II, seluruh kelompok peserta didik mendengarkan penjelasan prosedur kegatan yang disampaikan guru dengan baik.

Menurut Widiadnyana dkk, (2014) tahapan pengumpulan data melatih peserta didik untuk menggunakan metode ilmiah dalam menyelesaikan masalah, sehingga tidak mudah percaya pada sesuatu yang belum pasti kebenarannya. Seluruh kelompok peserta didik aktif pada saat mengumpulkan data diskusi maupun percobaan yang dilakukan.Di siklus I peserta didik mengamati dan mencatat komponen biotik dan abiotik yang ada di halaman sekolah. Sedangkan di siklus II peserta didik mengamati dan mencatat kemungkinan rantai makanan yang terjadi di sawah. Hal ini sesuai dengan pernyataan Nurgazali (2019) bahwa dalam pengaplikasiannya model discovery 
learning mengembangkan cara belajar siswa aktif dengan menemukan sendiri.

\section{Pengolahan Data}

Pada tahap pengolahan data ini terdapat satu indikator kegiatan guru maupun peserta didik.Kegiatan yang dilakukan guru adalah membimbing kelompok peserta didik dalam mengolah data hasil diskusi maupun percobaan.Pada siklus I, aktivitas guru pada tahap pengolahan data masih dinilai cukup oleh pengamat.Begitu pula, aktivitas peserta didik dalam pengolahan data. Hal ini dikarenakan pada tahap pengolahan data di siklus I, hanya 3-4 kelompok peserta didik saja yang dibimbing oleh guru dalam mengolah data hasil diskusi dan juga hanya ada 3-4 kelompok peserta didik yang menjawab pertanyaan pada LKPD sesuai dengan materi dan data yang diperoleh.

Pada siklus II dilakukan perbaikan berdasarkan refleksi di siklus I dimana guru telah membimbing seluruh kelompok peserta didik dalam mengolah data hasil percobaan mengenai rantai makanan dan piramida ekologi. Guru membimbing seluruh kelompok untuk mencatat hasil pengamatan yang telah dilakukan pada LKPD dan membimbing seluruh kelompok menjawab pertanyaan serta membuat kesimpulan dari hasil pengamatan yang telah didapatkan. Kegiatan yang dilakukan peserta didik ditahap ini adalah menjawab pertanyaan di LKPD.Kegiatan guru maupun peserta didik sesuai dengan Kemendikbud (2014) pengolahan data merupakan kegiatan mengolah data dan informasi yang telah diperoleh para siswa lalu ditafsirkan.

\section{Verification (Pembuktian)}

$$
\text { Pada tahap verification }
$$
(pembuktian) terdapat satu indikator kegiatan guru yakni, guru membimbing kelompok peserta didik dalam melakukan verifikasi/pembuktian data melalui membandingkan hasil diskusi maupun percobaan dengan buku/literatur lainnya.

Tahap pembuktian ini juga dilakukan dengan cara peserta didik mempresentasikan hasil diskusi bersama dengan anggota kelompoknya dan guru menambahkan atau mengarahkan hasil diskusi peserta didik ke bagian yang lebih benar. Menurut Widiadnyana, dkk (2014) tahap verifikasi, siswa melakukan pembuktian, perbaikan, dan pembenaran terhadap hasil yang diperoleh melalui presentasi dan diskusi kelas. Hal ini juga didukung oleh Widyastuti (2015) siswa dapat melakukan verifikasi ke kelompok lainuntuk mengetahui apakah pemikiran mereka sesuai dengan kelompok lain. Dari kegiatan ini peserta didik akan memperoleh pemahaman suatu konsep yang telah dipelajari.

6. Kesimpulan

Pada tahap kesimpulan terdapat satu indikator kegiatan guru yaitu, guru membimbing kelompok peserta didik untuk membuat kesimpulan hasil diskusi maupu percobaan materi ekosistem. Aktivitas guru pada tahap ini belum berjalan dengan baik di siklus I. Hal ini dikarenakan guru hanya membimbing 3-4 kelompok untuk membuat kesimpulan berdasarkan hasil dan tujuan pengamatan yang terdapat pada LKPD. Guru melakukan refleksi pada tahap ini di siklus II, sehingga terjadi peningkatan yang dapat dilihat dari perolehan skor yang diberikan oleh dua orang pengamat dalam kategori baik pada siklus II. Hal ini dikarenakan guru sudah membimbing 5-6 kelompok untuk membuat kesimpulan berdasarkan hasil dan tujuan percobaan tentang rantai makanan dan piramida ekologi pada Lembar Kegiatan Peserta Didik (LKPD).

Aktivitas belajar peserta didik pada tahap kesimpulan pada sikus I masih termasuk kategori cukup, karena hanya 
3-4 kelompok yang menyimpulkan hasil diskusi berdasarkan data hasil dan tujuan percobaan pada LKPD.Di siklus II dilakukan perbaikan oleh guru, sehingga seluruh kelompok dapat menyimpulkan hasil diskusi dan tujuan percobaan pada LKPD.Kegiatan membuat kesimpulan dilakukan peserta didik berdasarkan verifikasi. Menurut Kemendikbud (2014) tahap menarik kesimpulan adalah sebuah proses untuk merumuskan prinsip-prinsip berdasarkan hasil verifikasi.

\section{PENUTUP}

\section{Kesimpulan}

Berdasarkan hasil penelitian
bahwa penerapan model discovery learning dalam proses pembelajaran pada materi ekosistem dapat meningkatkan hasil belajar peserta didik di kelas VII B SMPN 22 Kota Bengkulu pada ranah kognitif dengan persentase ketuntasan klasikal 53,12\% di siklus I menjadi 75\% di siklus II. Pada ranah psikomotor rerata skor pada siklus I sebesar 9,28 dengan kategori cukup dan meningkat pada siklus II menjadi 10,63 dengan kategori baik.

\section{Saran}

Berdasarkan penelitian yang telah dilakukan, beberapa saran yang dapat dianjurkan oleh peneliti yaitu :

1. Untuk guru biologi dalam melaksanakan pembelajaran dengan menggunakan model Discovery Learning, harus lebih menguasai tahap-tahapan di model ini terutama ditahap identifikasi masalah, pembuktian dan kesimpulan.

2. Untuk peneliti yang melakukan penelitian selanjutnya yang menggunakan model Discovery learning ini, hendaknya harus memperhatikan kondisi peserta didik yang kurang aktif dalam proses pembelajaran pada ranah psikomotor. Untuk mencapai tujuan pembelajaran yang lebih baik guru harus membuat proses belajar semenarik mugkin agar peserta didik tertarik untuk belajar.

\section{DAFTAR PUSTAKA}

Arikunto, Suharsimi. 2010. Penelitian Tindakan Kelas. Jakarta: Bumi Aksara.

Astuti, Theresia Inovia,. Irdam Idrus,.Yennita. 2018. Penerapan Model Pembelajaran Discovery Learning intuk Meningkatkan Hasil Belajar Pada Materi Biologi Siswa SMP. Diklabio: Jurnal Pendidikan dan Pembelajaran Biologi. Vol (2) 1 : 5-9.

Fitri, Mariza dan Derlina. 2015. Pengaruh Model Pembelajaran Discovery Learning Terhadap Hasil Belajar Siswa Pada Materi Pokok Suhu dan Kalor. Jurnal Jurusan Fisika FMIPA 3(2): 94-95.

Dimyati dan Mudjiono. 2009. Belajar dan Pembelajaran. Jakarta: Rineka Cipta.

Kemendikbud. 2014. Ilmu Pengetahuan Alam. Jakarta: Kementrian Pendidikan dan Kebudayaan.

Kunandar. 2013. Penelitian Tindakan Kelas. Jakarta: PT Rajawali Pers.

Sani, Ridwan Abdullah dan Sudiran. 2014. Penelitian Tindakan Kelas Pengembangan Profesi Guru. Tangerang: Tsmart. 
Sudijono, Anas. 2014. Pengantar Evaluasi Pendidikan. PT. Raja Grafindo Persada. Jakarta.

Sugiyono. 2017. Statistika Untuk Penelitian. Bandung : Alfabeta.

Suhada, Rihwan,. Irdam Idrus,. dan Kasrina. 2019. Peningkatan Hasil Belajar Siswa Melalui Penerapan Model Pembelajaran Discovery Learning. Diklabio: Jurnal Pendidikan dan Pembelajaran Biologi. Vol (3) 1 : $32-40$.

Suprijono, Agus. 2012. Cooperative Learning Teori dan Aplikasi PAIKEM. Yogyakarta: Pustaka Belajar.

Suwarno, Wiji. 2014. Dasar-dasar Ilmu Pendidikan. Yogyakarta: Ar-Ruzz Media.

Widiadnyana, I. W., Sadia, I. W., \& Suastra, I. W. 2014. Pengaruh Model Discovery Learning Terhadap Pemahaman Konsep IPA dan Sikap IImiah Siswa SMP. Jurnal. Pembelajaran IPA. Vol $3(2): 45$.

Widyastuti, E.S. 2015. Penerapan Model Pembelajaran Discovery Learning Pada Materi Konsep Ilmu Ekosistem. Prosiding Seminar Nasional. 38 